\title{
METACHROMATIC LEUCODYSTROPHY: STUDY OF THE FREE AMINO ACIDS IN BLOOD, URINE, SALIVA AND CEREBROSPINAL FLUID
}

\author{
Ovidio D. Escalante * \\ ARY Domingos do AMARAL ** \\ Horacio M. Canelas *
}

In the study of 2 cases of metachromatic leucodystrophy, late juvenile form, an increase of the total amino acid content in urine was found. The results of the study of the free amino acids in blood, urine, saliva, and cerebrospinal fluid (CSF) by means of circular and two-dimensional chromatography, and high voltage electrophoresis, are the subject of this communication.

MATERIAL AND METHODS

\begin{abstract}
Material - Two familial cases (cousins) of the late juvenile type of metachromatic leucodystrophy were studied. The diagnosis was based on the clinical picture plus the finding of metachromatic bodies in urine (Austin test ${ }^{1}$ ), saliva, and CSF (Canelas et al. $^{12}$ ), as well as in biopsies of peripheral nerve, liver, and kidney. The clinical and laboratorial data on these cases are extensively reported elsewhere ".

The following samples were used: (a) recently emitted or 24-hour urine preserved with thymol; (b) $10 \mathrm{ml}$ of recent blood serum; (c) whole saliva obtained by mechanic stimulus (rubber ball chewing) for periods from 8 to 12 hours; (d) $10 \mathrm{ml}$ of recent CSF collected by lumbar puncture. The fluids were. kept in a refrigerator at $5^{\circ} \mathrm{C}$.

Methods - (a) Deproteination, according to Awapara ${ }^{3}$, Troll and Cannan ${ }^{57}$, Stein and Moore ${ }^{54}$, and Campos et al. $^{10}$. Two milliliters of each sample are added to $6 \mathrm{ml}$ of ethanol and then transferred to a glass-stoppered tube and left at room temperature for one hour. The volume now is centrifuged for 10 minutes at $2,000 \mathrm{rpm}$; $2.5 \mathrm{ml}$ of the supernatant are transferred to a graduated cylinder and completed up to $10 \mathrm{ml}$ with chloroform. The cylinder is shaken and then left in rest until the layers are separated. The acqueous upper layer contains amino acids (A).
\end{abstract}

(b) Hydrolysis of the biologic fluids: $0.5 \mathrm{ml}$ of the upper layer (A) are transferred to a $10 \mathrm{ml}$ ampoule; $0.5 \mathrm{ml}$ of $6 \mathrm{~N}$ hydrochloric acid are added; the ampoule is closed and put in a stove at $100-110^{\circ} \mathrm{C}$ for 24 hours. The ampoule is then opened

From the Department of Neurology* (Chairman: Prof. Adherbal Tolosa) and the Center of Nuclear Medicine ** (Director: Dr. Tede Eston; Head, Division of Eiological Research: Dr. Veronica Rapp de Eston), University of São Paulo School of Medicine, Brazil. This study was supported by a grant of the Brazilian Ministry of Health. 
and $0.9 \mathrm{ml}$ are transferred to a porcellain capsule immersed in water bath. The material is concentrated with ethanol and the hydrochloric acid is evaporated. The residuum is redissolved in $0.3 \mathrm{ml}$ of $10 \%$ isopropanol. In this way a sample of hydrclyzed amino acids is concentrated three times (B).

(c) Standards for comparison with the biologic samples were artificially obtained according to the most frequent amino acids in urine $7,8,20,36,88,52,59$, blood serum ${ }^{23}$,

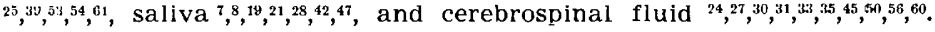

(d) The chromatographic technique followed the general rules of Block et al." and Lederer ${ }^{29}$, using as solvents a mixture $4: 1: 1$ of butanol, acetic acid and water, and a mixture 80:20 of phenol and water. For circular chromatography Whatman paper No. 1 was used. A 0.4 ninhydrin solution in $95 \%$ acetone in water was used for color development. Circular chromatographies in wooden cases, as well as twodimensional chromatography, always developed, in each chromatogram: the direct sample (A), the hydrolyzed sample (B), and the standard of the corresponding biologic fluid (C).

(e) High voltage electrophoresis was used in accordance to $\mathrm{H}$. Michl (apud Lederer ${ }^{29}$ ), Smith ${ }^{49}$, Block et al. ${ }^{9}$, Visakorpi and Puranen ${ }^{59}$, Efron ${ }^{17}$, and Mabry and Todd ${ }^{36}$. The controle were made with $4 \mathrm{kv}, 60 \mathrm{~mA}, 5 \mathrm{Lb}, 20$ minutes each, in an apparatus of high voltage*. The buffer solution was prepared with $2.5 \mathrm{ml}$ of pyridine, $10 \mathrm{ml}$ of acetic acid, and water up to $2,500 \mathrm{ml}(\mathrm{pH} \mathrm{5.3})$. Whatman paper $3 \mathrm{MM}, 12 \times 50 \mathrm{~cm}$, was used. The samples were placed in the center of the paper moistened with the buffer solution, and equally distant from the two poles. The lirect sample (A), the hydrolyzed sample (B), and the corresponding biologic fluid (C) were always used.

(f) The fluids were carefully led to the same concentration, each one being applied in the amount of $25 \mu \mathrm{l}$ for high voltage electrophoresis, $50 \mu \mathrm{l}$ for circular chromatography, and $100 \mu 1$ for two-dimensional chromatography.

\section{RESULTS}

The results are summarized in Table 1 . Emphasis will be given to the amino acid concentrations specifically altered in the CSF of the two patients in study. Plasma, urine, and saliva amino acid levels will be used as qualitative data.

Plasma - Seventeen of the 21 normal amino acids were found. The most increased amino acids were cystine, aspartic acid, glycine, glutamic acid, alanin, proline, tyrosine, and phenylalanin. Besides, 3 still unidentified substances (peptides? amino acid derivatives?.) were found: (1) between taurine and histidine; (2) between arginine and aspartic acid; (3) between serine and glutamic acid.

Urine - Seventeen of the 21 amino acids normally present in this fluid were found. The most increased amino acids were cystine, aspartic acid, alanin, proline, tyrosine, and phenylalanin. Besides, 3 still unidentified substances were found: (1) between taurine and histidine; (2) between arginine and aspartic acid; (4) between glutamine and threonine.

* Locarte Company, $10 \mathrm{kv}, 100 \mathrm{~mA}$. 
Table 1 - Study of the free amino acids in two cases of metachromatic leucodystrophy, juvenile type (with quantitative data on the most concentrated amino acids in the cerebrospinal fluid $-\mu \mathrm{g} / \mathrm{ml})$.

\begin{tabular}{|c|c|c|c|c|c|c|c|}
\hline & \multirow{2}{*}{ Amino acids } & \multirow{2}{*}{$\begin{array}{l}\text { Blood } \\
\text { serum }\end{array}$} & \multirow{2}{*}{ Saliva } & \multirow{2}{*}{ Urine } & \multicolumn{3}{|c|}{ Cerebrospinal fluid } \\
\hline & & & & & $O . A$. & M.A.R. & Normals \\
\hline 1. & Cystine & ++ & + & ++ & & & \\
\hline 2. & $\alpha-\gamma$-diaminobutyric & + & ++ & & & & \\
\hline 3. & Lysine & + & + & & + & + & + \\
\hline 4. & Taurine & + & & + & & & \\
\hline 5. & Unidentified No. 1 & + & t & + & + & + & \\
\hline 6. & Histidine & + & + & + & & & \\
\hline 7. & Arginine & + & + & + & + & + & + \\
\hline 8. & Unidentified No. 2 & $\ldots$ & & $\ldots$ & & & \\
\hline 9. & Aspartic acid & ++ & + & ++ & 50.3 & 13.2 & $0.4-1.2$ \\
\hline 10. & Glycine & ++ & + & + & + & + & + \\
\hline 11. & Serine & + & + & + & ++ & ++ & + \\
\hline 12. & Unidentified No. 3 & $\ldots$ & & & & & \\
\hline 13. & Glutamic acid & ++ & ++ & + & + & + & + \\
\hline 14. & Glutamine & + & & + & + & + & + \\
\hline & Unidentified No. 4 & & $\ldots$ & $\ldots$ & $\ldots$ & $\ldots$ & \\
\hline 16. & Threonine & & & + & + & + & + \\
\hline 17. & Alanin & ++ & ++ & ++ & 56.1 & 17.1 & $2.9-3.4$ \\
\hline 18. & Proline & ++ & ++ & ++ & 8.8 & 3.0 & 0.1 \\
\hline 19. & Tyrosine & $+t$ & + & ++ & + & + & + \\
\hline & Unidentified No. 5 & & $\ldots$ & & & & \\
\hline & Tryptophan & + & & + & & & \\
\hline & Valine & & & + & + & + & + \\
\hline 23. & Phenylalanin & ++ & & ++ & 40.4 & 12.3 & $1.5-1.8$ \\
\hline & Unidentified No. 6 & & & & $\ldots$ & $\ldots$ & \\
\hline 25. & Leucines & + & + & + & + & + & + \\
\hline
\end{tabular}

..., traces. * Logothetis ${ }^{30,31}$, Logothetis and Bovis ${ }^{33}$, Perry and Jones ${ }^{45}$.

Saliva - Thirteen of the 21 normal amino acids were found. The most concentrated amino acids were $\alpha^{-} \gamma$-diaminobutyric acid, glutamic acid, alanin, and proline. Besides, 3 still unidentified substances were found: (1) betwe $\in$ lysine and histidine; (4) between glutamic acid and alanin; between tyrosine and leucines. 
Cerebrospinal fluid - Fourteen of the 21 amino acids most constant in the normal controls were found. The most concentrated amino acids were aspartic acid, alanin, proline, and phenylalanin, mainly in patient O.A. (Table 1, Fig. 1). The remaining amino acids were present in levels paralleling the normal averages reported by most authors. Besides, 3 still unidentified substances were found: (1) between lysine and arginine; (4) between glutamine and threonine; (6) between phenylalanin and leucines.

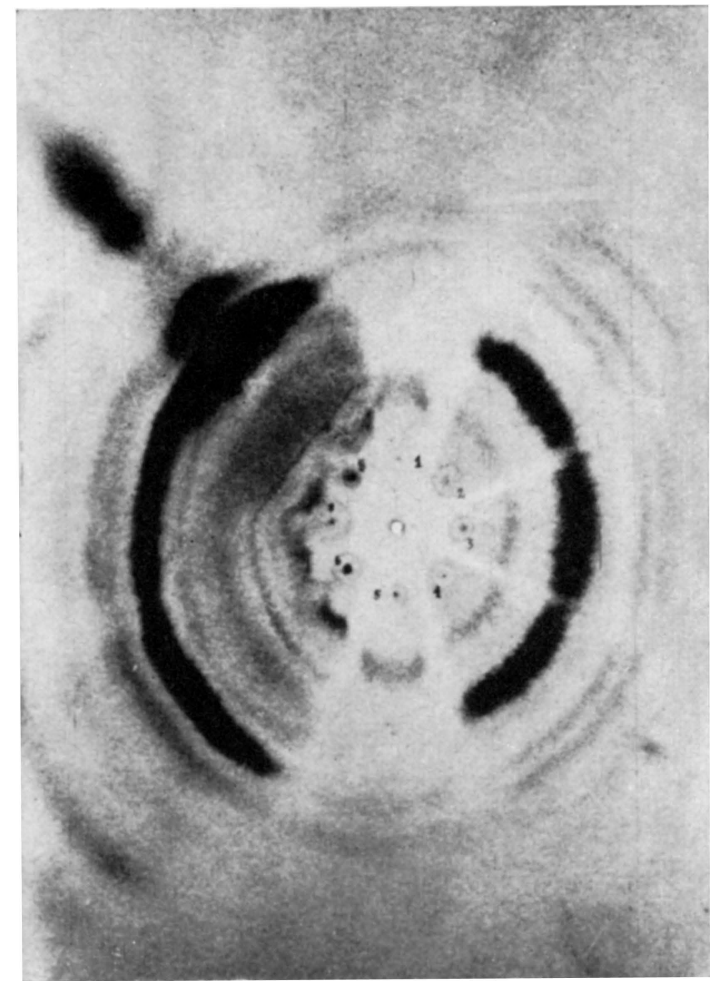

Figure 1 - Circular chromatogram of the free amino acids in the cerebrospinal fluid in a case (O.A.) of metachromatic leucodystrophy. The standard and the samples were applied in amounts of $500 \mu 1$. No. 1 and 5, standards of amino acids; No. 2,3 and 4 , free amino acids of the sample (direct extraction); No. 6,7 and 8 , hydrolysis of the amino acids of the sample.

Of particular interest is the marked increase of aspartic acid and proline, a finding not yet reported. From the unidentified components, the most frequent were (1) and (4). Through high voltage electrophoresis the component (1) was disintegrated into three parts (Fig. 2), one of them be- 
having like a polypeptide ${ }^{9}, 29,49$, and was seemingly identifiable with a compound substance containing glutamic acid, glycine, and aspartic acid, which prevails in the chromatographic and electrophoretic splittings.

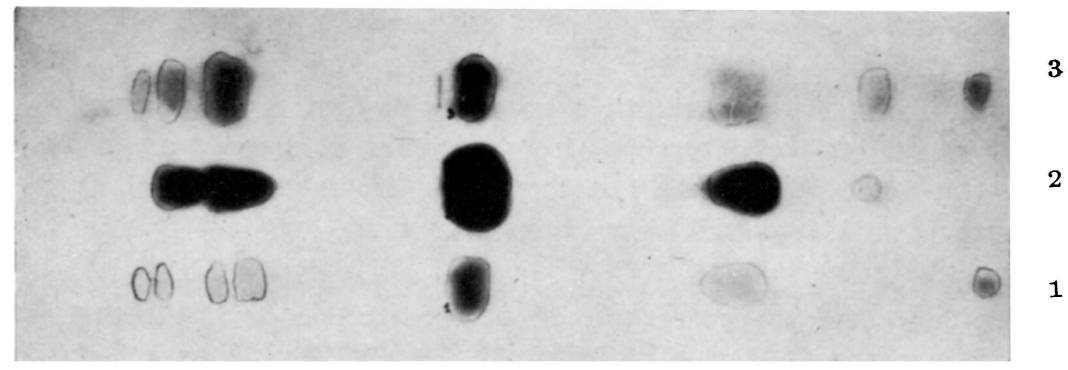

Figure 2 - High voltage electrophoresis of the free amino acids in the cerebrospinal fluid in a case (O.A.) of metachromatic leucodystrophy. No. 1, direct extraction of the amino acids $(25 \mu \mathrm{l})$; No. 2, standard of glutamic acid $(25 \mu 1)$; No. 3, hydrolisis of the amino acids $(25 \mu 1)$, showing a splitting in spots (peptides) migrating to the negative pole and corresponding to the unidentified spots No. 1 and 2 of the circular and two-dimensional chromatographies.

\section{COMMENTS}

The two cases with juvenile metachromatic leucodystrophy showed a marked aminoaciduria: patient O.A. $1,346.6 \mathrm{mg} /$ day, volume $1,380 \mathrm{ml}$; patient M.A.R. $411.5 \mathrm{mg} /$ day, volume $1,350 \mathrm{ml}$ (normal values, according to McEvoy-Bowe and Lugg ${ }^{38}$, and others: 64 to $110 \mathrm{mg} /$ day). In the cerebrospinal fluid, the total concentrations of amino acids were, respectively, 266 and

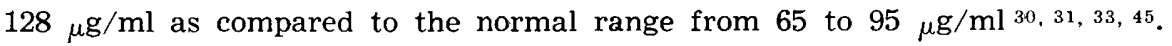

Liver and kidney function tests disclosed no definite impairment in these two cases; this is in accordance with the literature, the finding of kidney damage in metachromatic leucodystrophy being exceptional 43,62 . So, the increased aminoaciduria in these cases could be ascribed to a genetic error in the metabolism of amino acids, probably a specific enzymatic disorder. The physical and chemical characteristics make it similar to the renal aminoacidurias, either inborn or acquired $5,6,18,20,22,23,38,49,51$.

The polypeptide (glutaminyl-glycyl?) found in the CSF could be bound to an abnormal fraction also produced by an enzymatic inborn error, giving way to a specific polypeptide-lipid.

It must be reminded that deposits of mucopolysaccharides have been demonstrated in the white matter of cases with metachromatic leucodystrophy 16,58. Furthermore, in the granular cells of the brain in adult cases of this disease, Diezel ${ }^{16}$ found a glycolipid-proteid complex. In another neurolipidosis, gargoylism, the cerebral cells store gangliosides, while the liver and kidney cells store mucopolysaccharides, which are heavily excreted in urine 40,55 . 
Rcgarding the disorders of amino acid concentrations in CSF, it deserves mentioning that in Niemann-Pick disease Logothetis and Bovis ${ }^{34}$ found an increase of aspartic acid, tyrosine, glycine, valine, arginine, alanin, leucine, serine, and lysine. In one case of cerebromacular degeneration the same authors fcund an increase of glutamic and aspartic acids, tyrosine, arginine, alanin, serine, and glutamine.

While in 12 cases of multiple sclerosis Walker et al. ${ }^{60}$ found no quantitative or qualitative differences from normals, in 4 cases of "diffuse sclerosis" (type not mentioned) Logothetis and Bovis ${ }^{34}$ evidenced an increase of glutamic and aspartic acids, tyrosine, valine, arginine, alanin, leucine, serine, and lysine.

The increased concentrations of $\gamma$-amincbutyric acid, tyrosine, glycine, and serine in the CSF of a patient with familial spastic paraplegia, studied by Logothetis and Bovis ${ }^{34}$, must be emphasized. Actually, Scholz ${ }^{48}$, Curtius ${ }^{14}$, Poser and van Bogaert ${ }^{46}$, and Kastan ${ }^{26}$ found several cases of Strümpell's parapleg:a in families of patients with metachromatic leucodystrophy, suggesting a genetic relationship between the two diseases. In 2 cases of hereditary ataxia, a nosologic group closely related to familial spastic paraplegia, Logothetis ${ }^{32}$ found a significant increase of aspartic acid, while alanin, serine, glycine, lysine and threonine appeared moderately elevated. In 3 further cases of "heredoataxias", Logothetis and Bovis ${ }^{34}$ evidenced an increase of $\gamma$-aminobutyric acid, glutamic acid, aspartic acid, arginine, and serine.

One can easily admit that the metabolism of amino acids in the central nervous system is deeply impaired in those disease processes, since the bloodbrain barrier would prevent the passage to the CSF of the most concentrated amino acids in blood plasma.

Concerning the disorders of amino acid concentrations in urine, we remind that, in Wilson's disease, an increased excretion of threonine, cystine, lysine, serine and tyrosine, and less marked of glutamine and alanin, is found $6,13,49,53$; in the CSF the amino acid concentrations are only slightly changed, perhaps because the disorder depends more on the kidney than on the brain damage.

In "maple syrup" disease, where the prescnce of mental impairment, spasticity and myoclonus reflects the nervous involvement, an increase of valine, leucine, and isoleucine is found; the evidence of a great amount of indole components points to an interference in the metabolism of tryptophan $15,18,22,37$.

In Hartnup disease - a hereditary condition characterized by progressive mental deterioration and transient cerebellar ataxia, besides of other manifestations - an increase of alanin, serine, glutamine, valine, leucines, tyrosine, phenylalanin, tryptophan and histidine is found $5,18,22,41,49$.

In phenylketonuria, the urinary excretion of phenylalanin and its metabolites is increased 2, 18, 44,49; this metabolic disorder and the mental impair- 
ment are two features in common with our cases of metachromatic leucodystrophy.

It must be emphasized that in phenylkctonuria, "maple syrup" disease and in Lowe's syndrome (another disease involving a disorder of the metabolism of amino acids), retarded myelination and gliosis have been found ${ }^{4}$.

In the CSF of our cases we found a marked increase of aspartic acid, alanin, proline, and phenylalanin, and a moderate rise of serine, the remaining amino acids being in normal levels; this pattern resembles those found by Logothetis and Bovis ${ }^{34}$ in Niemann-Pick disease, cerebromacular degeneration, and in "diffuse sclerosis". In urine the prevailing amino acids were cystine, aspartic acid, alanin, proline, tyrosine, and phenylalanin, a pattern which resembles that of Hartnup disease.

It can not be taken for granted that the increased concentrations and abnormal presence of amino acids in urine and CSF of our cases of Scholz disease are caused by an inborn error, since we could not perform the same investigation in the youngest relatives of them. However, it can be presumed that the amino acid dysmetabolism would chronologically follow the lipid disordel.

\section{SUMMARY}

Increased aminoaciduria in metachromatic leucodystrophy is demonstrated, presumably for the first time. By means of circular and two-dimensional chromatography, the free amino acids of urine, blood, saliva, and cerebrospinal fluid of two familial cases of juvenile metachromatic leucodystrophy were studied.

In blood an increased concentration of cystine, aspartic acid, glycine, glutamic acid, alanin, proline, tyrosine, and phenylalanin was found. In urine, cystine, aspartic acid, alanin, proline, tyrosine, and phenylalanin showed increased levels. In saliva $\alpha^{-} \gamma$-diaminobutyric acid, glutamic acid, alanin, and proline were mostly concentrated. In cerebrospinal fluid aspartic acid, alanin, proline, and phenylalanin were found in greater concentrations.

Besides, 6 non-identified amino acids were present. One of them disintegrated into 3 components and one of these fractions behaved like a polypeptide, seemingly identifiable to a compound substance of glutamic acid, glycine, and aspartic acid. This substance could integrate a polypeptidlipid complex resulting from a lipid dysmetabolism, already known in the leucodystrophies, allied to a proteid dysmetabolism, now reported.

The results are compared with the data reported in the literature regarding the concentrations of amino acids in the cerebrospinal fluid and urine of some nervous diseases showing demyelinating processes. In CSF the pattern of metachromatic leucodystrophy resembles those previously found in Niemann-Pick disease, cerebromacular degeneration, and "diffuse sclerosis". In urine the pattern resembles that of Hartnup disease. 


\section{RESUMO}

Leucodistrofia metacromática: estudo dos aminácidos livres nos sangue, urina, saliva e líquido cefalorraqueano.

É registrado, presumivelmente pela primeira vez na literatura, o aumento da aminacidúria em casos de leucodistrofia metacromática. Mediante cromatografia circular e bidimensional foram estudados os aminácidos livres na urina, sangue, saliva e líquido cefalorraqueano de dois casos familiais de leucodistrofia metacromática.

No sangue foi verificado aumento da concentração de cistina, ácido aspártico, glicina, ácido glutâmico, alanina, prolina, tirosina e fenilalanina. $\mathrm{Na}$ urina encontravam-se elevados o ácido aspártico, cistina, alanina, prolina, tirosina e fenilalanina. $\mathrm{Na}$ saliva foi notado aumento do ácido $\alpha$ - $\gamma_{\text {-dia- }}$ minobutírico, ácido glutâmico, alanina e prolina. No líquido cefalorraqueano o ácido aspártico, alanina, prolina e fenilalanina encontravam-se em maiores concentrações.

Além disso, estavam presentes 6 aminácidos não identificados. Um dêles desintegrava-se em três componentes e uma destas frações comportava-se como um polipeptídeo, provàvelmente identificável a uma substância composta de ácido glutâmico, glicina e ácido aspártico. Esta substância poderia integrar um complexo polipéptido-lipídico resultante de um dismetabolismo lipídico, já conhecido nas leucodistrofias, associado a um distúrbio do metabolismo protêico, agora relatado.

Os resultados são comparados com os dados referidos na literatura relativa às concentrações de aminác:dos no líquido cefalorraqueano e urina de algumas afecçōes nervosas de caráter desmielinizante. No líquido cefalorraqueano o perfil da leucodistrofia metacromática se assemelha aos anteriormente encontrados na moléstia de Niemann-Pick, na degeneração cerebromacular e na "esclerose difusa". Na urina as alterações se aproximam das cue ocorrem na moléstia de Hartnup.

ACKNOWLEDGMENTS - We are indebted to Dr. Yolanda Tavares, head of the Section on Biochemistry of the Instituto Adolfo Lutz (Säo Paulo, SP, Brazil) for the assistance in the technical elaboration of this manuscript.

\section{REFERENCES}

1. AUSTIN, J. H. - Metachromatic form of diffuse cerebral sclerosis. I: Diagnosis during life by urine sediment examination. Neurology (Minneap.) 7:415-426, 1957. 2. ARMSTRONG, M. D.; SHAW, K. N. F. - Studies on phenylketonuria. III: The metabolism of o-tyrosine. J. biol. Chem. 213:805-811, 1955. 3. AWAPARA, J. - Application of paper chromatography to the estimation of free amino acids in tissues. Arch. Biochem. 19:172-173, 1948. 4. BARGETON, E. - The metachromatic form of leucodystrophy and its relationship to lipidosis and demyelination in other metabolic disorders. In Folch-Pi, J. \& Bauer, H. J.: Brain Lipids and Lipoproteins, and the Leucodystrophies. Amsterdam, Elsevier, 1963, p. 101. 5. BARON, D. N.; DENT, C. E.; HARRIS, H.; HART, E. W.; JEPSON, J. B. - Hereditary pellagralike skin rash with temporary cerebellar ataxia, constant renal aminoaciduria, and othər bizarre biochemical features. Lancet ii:421-428, 1956. 6. BEARN, A. G.; KUNKEL, H. G. - Abnormalities of copper metabolism in Wilson's disease and 
their relationship to the aminoaciduria. J. clin. Invest. 33:400-409, 1954 . 7. BERRY, H. K. - Further studies in individual urinary and salivary amino acid patterns. Univ. Texas Publ., No. 5109, p. 157-164. 8. BERRY, H. K.; CAIN, L. - Quantitative studies of urinary and salivary amino acids using paper chromatography. Univ. Texas Publ., No. 5109, p. 71-76. 9. BLOCK, R. J.; DURRUM, E. L.; ZWEIG, G. A Manual of Paper Chromatography and Paper Electrophoresis. New York, Academic, 1955. 10. CAMPOS, J. V. M.; ROTHSTEIN, W.; PONTES, J. F. - A dosagem do nítrogênio amínico no sôro sangüineo e na urina pelo método de Troll e Cannan. Rev. Hosp. Clín. Fac. Med. São Paulo 13:284-290, 1958. 11. CANELAS, H. M.; ESCALANTE, O. D.; IRIYA, K.; De JORGE, F. B. - Leucodistrofia metacromática: estudo clínico-laboratorial de cinco casos na mesma familia. Rev. paul. Med. 63:355376, 1963. 12. CANELAS, H. M.; ESCALANTE, O. D.; IRIYA, K.; De JORGE, F. B. - The diagnosis of metachromatic leucodystrophy during life: metachromatic lipids in saliva and cerebrospinal sediments and in the parotid glands. Arq. Neuropsiquiat. (S. Paulo) 22:122-128, 1964. 13. COPPER, A. M.; ECKARDT, R. D.; FALOON, W. E.; DAVIDSON, C. S. - Investigation of the aminoaciduria in Wilson's disease (hepatolenticular degeneration): demonstration of a defect in renal function. J. clin. Invest. 29:265-278, 1950. 14. CURTIUS, F. - Familiäre diffuse Sklerose und familiäre spastische Spinalparalyse in einer Sippe: ein Beitrag zur Genealogie der Fieredodegenerationen. Z. ges. Neurol. Psychiat. 126:209-227, 1930. 15. DANCIS, J. M.; LEVITZ, M.; MILLER, S.; WESTALL, R. G. - Maple syrup urine disease. Brit. med. J. i:91-93, 1959. 16. DIEZEL, P. B. - Lipidosis of the central nervous system. In Cumings, J. N.: Modern Scientific Aspects of Neurology. London, Arnold, 1960, p. 135. 17. EFRON, M. L. - Two-way separation of amino acids and other ninhydrin-reacting substances by high-voltage electrophoresis followed by paper chromatography. Biochem. J. 72:691-694, 1959. 18. EVERED, D. F. - The excretion of amino acids by the human; a quantitative study with ion-exchanging chromatography. Biochem. J. 62:416-427, 1956. 19. FOSDICK, L. S.; BLACKWELL, R. Q. - The aetermination of amino acid content of fresh and putrified saliva by paper partition chromatography. J. dent. Res. 28:644, 1949. 20. FOWLER, D. I.; NORTON, P. M.; CHEUNG, M. W.; PRATT, E. L. - Observations on the urinary amino acids excretion in man; the influence of age and diet. Arch. Biochem. 68:452-466, 1957. 21. GOLDBERG, H. J. V.; GILDA, J. E.; TISHKOPF, G. H. - Paper partition chromatography: free amino acids in saliva. J. dent. Res. 27:493-496, 1948. 22. HARPER, H. A.; DOOLAN, P. D. - The renal aminoacidurias. Clin. Chem. 9:19-26, 1963. 23. HIER, S. W.; BERGEIM, O. - The microbiological determination of certain amino acids in human and dog plasma. J. biol. Chem. 163:129-135, 1946. 24. HUISMAN, T. H. J. - Onderzoek naar het gehalte aan verschillende aminoazuren van de liquor cerebrospinalis. Ned, T. Geneesk. 99:3357-3361, 1955. 25. JOHNSON, C. A.; BERGEIM, O. - The distribution of free amino acids between erythrocytes and plasma in man. J. biol. Chem. 188:833-838, 1951. 26. KASTAN, M. - Different forms of diffuse sclerotic process - Pelizeus-Merzbacher disease, Struempell's familial spastic paralysis, leucodystrophy - in one family. J. nerv. ment. Dis. 101:357-362, 1945. 27. KEMALI, P. - Sulle eredo-degenerazioni spino-cerebellari e sulle relative forme di associazione. Acta neurol. (Napoli) 9:358-380, 1954.28. KIRCH, E. R.; KESEL, R. G.; O'DONNELL, J. F.; WACH, E. C. - Amino acids in human saliva. J. dent. Res. 26:297-301, 1947. 29. LEDERER, M. - Chromatographic Reviews: Progress in Chromatography, Electrophoresis and Related Methods. Amsterdam, Elsevier, 1959. 30. LOGOTHETIS, J. - A study of free amino acids in the human cerebrospinal fluid. Neurology (Minneap.) 5:767-776, 1955. 31. LOGOTHETIS, J. - Free amino acid content of cerebrospinal fluid in humans and dogs. Neurology (Minneap.) 8:299-302, 1958. 32. LOGOTHETIS, J. - Cerebrospinal fluid free amino acids in neurologic diseases: observations in aspartic acid concentrations. Neurology (Minneap.) 8:374-376, 1958. 33. LOGOTHETIS, J.; BOVIS, M. - Quantitative two-dimensional chromatography for free amino acids in cerebrospinal fluid analysis. Wld Neurol, 2:747-761, 1961. 34. LOGOTHETIS, J.; BOVIS, M. - Free amino acids changes in the spinal fluid of patients with central nervous system degenerative and chronic epileptic disorders. Wld Neurol. 3:466-474, 1962. ¿j. LUDEWIG, S. - Glutamine, glutamic acid, and $\gamma$-aminobutyric acid in cerebro- 
spinal fluids. Arch. Neurol. Psychiat. (Chic.) 70:268-270, 1953. 36. MABRY, C. C.; TODD, W. R. - Quantitative measurement of individual and total free amino acids in urine. J. Lab. clin. Med. 61:146-157, 1963. 37. MACKENZIE, D. Y.; WOOLF, L. I. - Maple syrup urine discase; an inborn error of the metabolism of valine, leucine, and isoleucine associated with gross mental deficiency. Brit. med. J. i:90-91, 1959. 38. McEVOY-BOWE, E.; LUGG, J. W. - A direct quantitative paper chromatography of amino acids and its application to the urinary excretion of some human ethnic groups. Biochem. J. 80:616-623, 1961. 39. McMENAMY, R. H.; LUND, C. C.; ONCIEY, J. L. - Unbound amino acid concentrations in human blood plasma. J. clin. Invest. 36:1672-1679, 1957. 40. MEYER, K.; GRUMBACH, M. M.; LINKER, A.; HOFFMAN, P. - Excretion of sulfated mucopolysaccharides in gargoylism (Hurler's syndrome). Proc. Soc. exp. Biol. (N.Y.) 97:275-279, 1958. 41. MILNE, M. D.; CRAWFORD, M. A.; GIRAO, C. B.; LOUGHRIDGE, L. - The metabclic abnormality of Hartnup disease. Biochem. J. 72:30-31P, 1959. 42. MOOR, J. R.; GILLIGAN, D. R. - Paper partition chromatography of free amino acids and peptides of normal human saliva. J. nat. Cancer Inst. 12:691-697, 1951. 43. NOR.. MAN, R. M. - Diffuse progressive metachromatic leucoencephalopathy: a form of Schilder's disease related to the lipidoses. Brain 70:234-250, 1947. 44. PARE, C. M.; SANDLER, M.; STACEY, R. S. - Decreased 5-hydroxytryptophan decarboxylase activity in phenylketonuria. Lancet ii:1C99-1101, 1958. 45. PERRY, T. L.; JONES, R. T. - The amino acid content of human cerebrospinal fluid in normal individuals and in mental defectives. J. clin. Invest. 40:1363-1372, 1961. 46. POSER, C. M.; Van BOGAERT, L. - Natural history and evolution of the concept of Schilder's diffuse sclerosis. Acta psychiat. neurol. scand. 31:285-331, 1956. 47. ROSE, G. A.; KERRER, A. C. - The amino acids and phosphoethanolamine in salivary gland secretions of normal men and of patients with abnormal calcium, phosphorus and amino acid metabolism. Quart. J. exp. Physiol. 43:160-168, 1958. 48. SCHOLZ, W. - Klinische, pathologisch-anatomische und erbbiologische Untersuchungen bei familiärer, diffuser Hirnsklerose im Kindesalter (ein Beitrag zur Lehre von den Heredodegenerationen). Z. ges. Neurol. Psychiat. 99:651-717, 1925. 49. SMITH, I. Chrcmatographic and Electrophoretic Techniques. London, Heinemann, 1960.50. SOLOMON, J. D.; HIER, S. W.; BERGEIM, O. - Free amino acids in cerebrospinal fluid. J. biol. Chem. 171:695-7C0, 1947. 51. STAMBAUGH, R.; DAVIDSON, D. T., Jr.; ELKINTON, J. R. - Variation in excretion of certain amino acids with age. Clin. Chem. 9:210-216, 1963. 52. STEIN, W. H. - A chromatographic investigation of the amino acid constituents of normal urine. J. biol. Chem. 201:45-58, 1953.53. STEIN, W. H.; BEARN, A. G.; MOORE, S. - The amino acid content of the blood and urine in Wilson's disease. J. clin. Invest. 33:410-419, 1954. 54. STEIN, W. H.; MOORE, S. - The free amino acids of human blood plasma. J. biol. Chem. 211: 915-926, 1954. 55. STEINESS, I. - Acid mucopolysaccharides in urine in gargoylism. Pediatrics 27:112-117, 1961. 56. TORRE, M.; SCARZELLA, R.; ZANALDA, A. Ricerca cromatografica con dati quantitativi degli aminoacidi liberi nel liquor di soggetti normali. Boll. Soc. ital. Biol. sper. 29:196-198, 1953. 57. TROLL, W.; CANNAN, R. K. - A modified photometric ninhydrin method for the analysis of amino and imino acids. J. biol, Chem. 200:803-811, 1953. 58. URICH, H. - Proc. 4th Int. Congr. Neuropath., Munich, 1:42, 1961. Apud Norman, R. M.: Lipid diseases of the brain. In Williams, D.: Modern Trends in Neurology. London, Butterworth, vol. 3, 1962, p. 178. 59. VISAKORPI, J. K.; PURANEN, A. L. - High voltage paper electrcphoresis: a rapid method for determination of urinary amino acids. Scand. J. clin. Lab. Invest. 10:196-202, 1958. 60. WALKER, B. S.; TELLES, N. C.; PASTORE, E. J. - Amino acids of the cerebrospinal fluid: normal paper chromatographic pattern and its dupplication in multiple sclerosis. Arch. Neurol. Psychiat. (Chic.) 73:149-157, 1955. 61. WALKER, D. G.; PRASAD, A. S.; SADRIEH, J. Free amino acid levels in ultrafiltrates of human blood plasma. J. Lab. clin. Med. 59:110-117, 1962. 62. WITTE, F. - Uber pathologische Abbauvorgänge im Zentralnervensystem. Münch. med. Wschr. 68:69-82, 1921. 